\title{
Hospital Health Provider Behavior in Waste Application Based on Occupational Safety and Health Analysis
}

\author{
Achmad Delianur Nasution ${ }^{1 *}$, Eka Lestari Mahyuni ${ }^{2}$ \\ ${ }^{1}$ Universitas Sumatera Utara Hospital, Director of Infrastructure and Medical Facilities, Medan, Indonesia; ${ }^{2}$ Department of \\ Occupational Safety and Health, Faculty of Public Health, Universitas Sumatera Utara, Medan, Indonesia
}

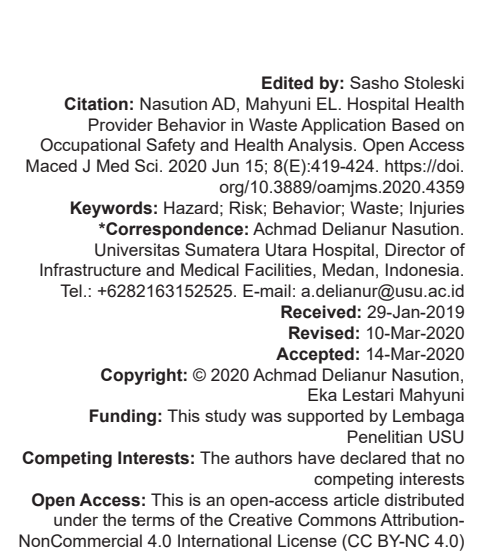

\begin{abstract}
BACKGROUND: Hospitals have potential hazards that increase the incidence of accidents or occupational diseases.

AIM: This study aims to analyze occupational safety and health $(\mathrm{OSH})$ risks in waste management regarding the behavior of hospital health provider.

METHODS: This is an explanatory research with a cross-sectional design. The population were all health providers and janitors in hospital. Random sampling technique was chosen to obtain the study sample. Data was collected from observation and interview regarding waste disposal including solid waste and sharp objects. It analyzed using descriptive statistic.

RESULTS: The results found that health providers had a poor behavior in managing waste such as disposing garbage not in accordance with the predetermined containers provided by the hospital management, mixing infectious waste with sharp objects, and did not care to dispose garbage at the designated place while disregarding the corresponding waste containers

CONCLUSIONS: The potential risk of accidents were very high for janitors, specifically in the extreme risk category. We recommend to increase the $\mathrm{OSH}$ standard procedure for janitors. Here, the hospital prepares special red garbage
\end{abstract} with Marca of needle stick injuries to help janitor classify the infectious waste.

\section{Introduction}

Hospital is a health institution with various disciplines and expertise to carry out activities in preventive, curative, promotive, and rehabilitative health services, rendering the hospital as an organizers of public service activities [1]. Hospitals as labor-, expert-, capital-, and technology-intensive service industries which also have potential hazards and complexity of risks that increase the incidence of workplace accidents or occupational diseases. Based on previous research, so many risks could happen in hospital activities like drug administration error, incorrect operation of medical equipment, error in patient identification, needle stick injuries, work-related disease from sharp injuries at night duty, blood exposure, splash exposure, body fluids exposure among health care, and occupational safety precautions among nurses [2], [3], [4], [5], [6]. All of these risks can ktisptif the cause is due to the behavior of health provider themselves in managing medical or nonmedical waste. For this reason, hospitals are required to implement Occupational Safety and Health $(\mathrm{OSH})$ which is integrated into hospital management system. OSH implementation be carried out thoroughly, including in managing hospital waste.
Hospital waste generally consisted of medical waste and non-medical waste. Based on its nature, the concentration and amount of hospital waste can be detrimental to health and can pollute the environment [7]. Hospital waste also contains toxic chemicals and sharp objects causing hospital waste to be infectious, toxic, and/or radioactive [8]. Hospital waste can be considered as a chain for the spread of infectious diseases and carries the risk of danger that has the potential to cause workplace accidents and work-related illnesses. In Indonesia, only $49 \%$ of 1176 hospitals (526 government hospitals and 652 private hospitals) in 30 provinces, only 648 hospitals have incinerators and $36 \%$ have an installation of a Waste Water Treatment Plant (WWTP) with non-working conditions. For solid waste management, $80.7 \%$ have already separated between medical waste and non-medical waste. But for storage, only $20.5 \%$ use special storage with different colors and symbols [9], [10].

Therefore, the purpose of this study was to analyze the behavior of health providers based on safety and occupational health aspects in the management of hospital waste at Hospital-Universitas Sumatera Utara (H-USU). 


\section{Methods}

This study has met the ethical clearance criteria approved by Faculty of Nursing Universitas Sumatera Utara with number 1952/II/SP/2019. This was an explanatory research where the objective was to explain all processes that showed how the health providers manage waste while providing patient service. It was related to how the cleaning service manage the waste collected from rooms or wards. The effect from the health providers will impact waste management using cross sectional design. The population in this study were all health providers and janitors at Hospital USU, Medan, Indonesia.

The sampling technique was incidental random sampling with the main criteria of active health providers during the study. The study subjects were 35 health providers (mostly nurses) and janitors from $\mathrm{H}$-USU. Data was collected through observation method on the behavior of disposing solid waste, namely sharp objects and solid waste used during health service process. We analyzed the data using descriptive statistics based on aspects of occupational safety and health [11], [12].

\section{Results and Discussion}

The Hospital Universitas Sumatera Utara (HUSU) is a hospital that provides educational and global health services to the community, especially for people in Medan, Sumatera Utara. The process of waste management is coordinated by the management and carried out through second parties. In managing hospital waste, H-USU implements a temporary solid waste disposal system and waste management through WWTP. H-USU has an incinerator but cannot be used and sometimes the final waste is also managed by a third party.

Based on the research conducted, management of medical and non-medical waste at HUSU has been sorted using special containers with colors and symbols. But the behavior of health providers was still not in accordance with the established management program. There were still 24 nurses (68.6\%) who disposed sharp objects along with other medical or non-medical waste. The needle stick waste usually was more important to analyze because it was more hazardous. There were 22 health providers $(62,9 \%)$ not following waste management procedures (See Figure 1). We observed that the health providers were more careful in managing waste in the form of patient's blood or body fluids, as well as the chemicals used in their work processes, whether for solid waste or needle stick. On the other hand, the health providers showed less care for other waste disposals when they mix the

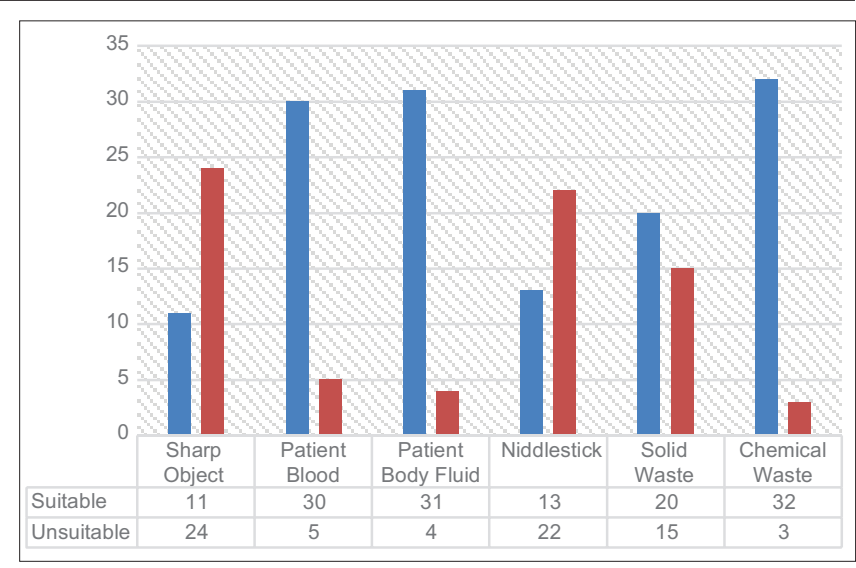

Figure 1: Health provider behavior in waste application

needle stick with cotton or gauze after treating a patient or other services. Such health workers had been found by the hospital management and emphasizing the gap between knowledge and actual practice regarding health care in waste management. It needed training, organizational changes, monitoring, and generation of information relevant to the microsystem studied but also to other institutions in similar settings [5].

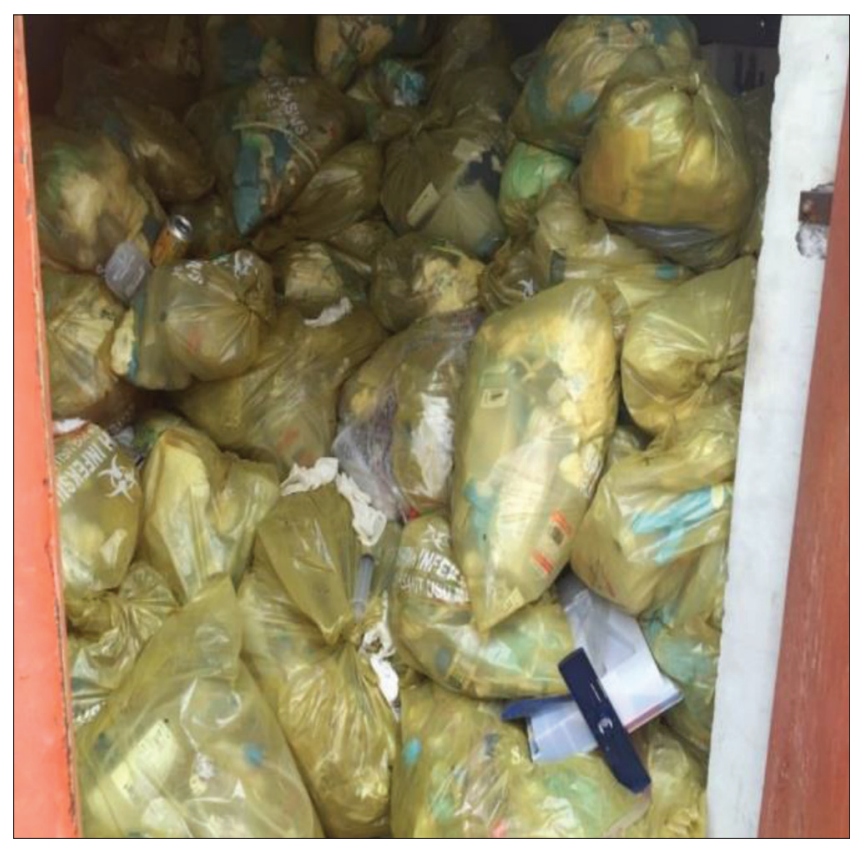

Figure 2: Temporary storage place

Exposure of blood, body fluid, or biomedical waste when poorly managed can increase the prevalence of hepatitis, AIDS, and related infection. It is called work related injuries showed by incidence of needle stick injuries or exposure by sharp objects. It mainly happened in the morning duty and on the palm of the right hand. Most incidents happened because the health worker was not wearing a personal protective device.

Sharp injuries usually were caused by hazardous work environment conditions with specific risk factors. In the London study [16], the most frequently occurring exposures involved contact with sharps, infectious agents, and hazardous substances; personal 
injuries during waste handling; manual handling injuries; slips, trips and falls; and striking against or being struck during procedures. Approximately $65 \%$ of the reported exposures occurred within the wards and for this location, highly significant correlations were found between nurses and contact with sharps [13], [14], [15], [16], [17].

Management of medical and non-medical waste at $\mathrm{H}$-USU is carried out with a subcontract system with other parties. They were responsible for maintaining hospital cleanliness and managing hospital solid waste, starting from collecting garbage from every room, sorting medical and non-medical waste, to placing waste in the Temporary Storage Site (TSS). This process provided direct or indirect hazard for housekeeping or health workers.

The source of exposure came from the equipment and direct contact with the waste disposal. It was classified as high risk exposure if the health providers did not sort the waste properly, classify into toxic waste, biomedical waste, sharp and syringe waste, and others. However, solid waste processing facilities also could be giving the occupational exposure from landfill and waste vehicle surface. The important thing to prevent the impact of solid waste exposure was waste segregation (separation) and identification [18], [19]

For garbage management, the hospital provided standards with symbols and information to classify the nature and type of waste. The trash was divided into two categories, namely Infectious Waste and Non-Infectious Waste. The management of garbage disposal in the health services section has been socialized by Hospital Infectious Disease Control (HIDC) officers. Infectious waste was collected in yellow plastic containers and non-infectious waste was collected in black plastic containers. Whereas for infectious waste in the form of sharp objects such as syringes and other sharp objects, it was collected in special disposal containers or popular as the Safety Box.

Basically, the hospital has managed hospital waste properly, but in its implementation there were still hygiene problems shown by the inappropriate behavior of garbage or medical waste disposal. The terms of waste management in general takes place in implementation of regulations related to health of hospitals but not for the community. In reality, hospital environmental health activities were still not a priority. According to this, usually the actions were none correctly matched with the research conducted such as placing waste in appropriate containers according to category and storing the waste in dustbins. Here is the need to evaluate how to implement environmental impact analysis with efforts from the management and to monitor the hospital environment [20], [21]. Overall, it showed that hospitals services are still administratively oriented. It has to change to improve hospital waste management. For reference, the research has reform how the role of the hospital in changing environment by integrating strategies of behavioral interventions; using financial incentives; and changing organization culture [23]. The hospital should be careful to create a health environment that is commonly contaminated and infected from environmental surfaces frequently [22].

Based on the study results, health workers had poor behavior in managing waste. Nurses did not care and did not dispose garbage in accordance with the container that had been provided. It was determined by the hospital management of around 31 nurses (88.6\%). Meanwhile, 26 subjects $(74.3 \%)$ removed sharp, infectious waste, which is still joined by garbage that is not sharp. There were times when health providers $(34.3 \%)$ also did not care and immediately dispose garbage in its place disregarding the provided containers. This behavior was quite often found in health providers who dispose of the remaining syringes in any place [25] where as many as $10.4 \%$ of workers mix needles with other garbage. The nurses did not separate medical and non-medical waste and did not place in the provided containers. It were placed in nierbeken and was directly mixed with other waste [8]. Actually, there were three general intended waste management behaviors such as conservation of waste material; reuse of the material, and deciding before discarding waste [23].

Based on the interview results, this behavior occurred due to the high burden of the health providers, which cause them to rush in disposing garbage without sorting it out first. Another reason was caused by the character of health providers who were less concerned and lazy to use the containers provided. For example, throwing syringes into the safety box while actually the workers must open the safety box first considering the safety box provided was an easy pack. Sometimes health providers complain because the safety box is made of fragile material and they thought that there were still others who will sort the garbage. Waste separation is the main problem in healthcare waste practice with correct separation being positively related to the degree of daily contact with the waste. Risk perceptions of health providers showed that the environment, waste workers, and the lowest for patients and visitors, again being positively associated with the degree of daily contact. Risk perceptions of health workers were related to the difficulties of the correct separation of waste and the lack of knowledge concerning the importance of separation [24].

The behavior of health providers had an impact on hospital janitors (SAS, Sukses Anugerah Sejahtera, Ltd.) who played a role in collecting garbage from each room in the hospital. The behavior of mixing infectious waste in the form of sharp objects such as syringes with other garbage made it difficult for janitors to work and also posing a risk for occupational safety and health. The workers must sort the sharp infectious waste. This sorting process can increase the number of workplace accidents due to needles in the hospital environment. 
Proper and judicious handling of biomedical waste continues to be a matter of serious concern for health authorities in India [25]. Different with Ethiopia that approved segregation and removal from the health care establishments. It concluded that the health care waste management practices, diseases transmission from healthcare waste, and training were significantly associated with healthcare waste management practices of healthcare workers [26].

In line with the research conducted by Maironah et al. citing that according to WHO [27] that causes a person to behave cause of 4 reasons, namely, thoughts and feelings which include knowledge, beliefs, and attitudes, important people as references, resources in the form of facilities, time, money, knowledge and skills, and culture that have a major influence on behavior.

Overall the behavior in waste management depends on the personal factors which can solve waste management problem. Personal factors relate to recycling, although the greatest potential for improvement was identified in organizational issues, mainly concerning information, feedback, and logistics [28].

Based on aspects of occupational safety and health through work risk analysis, SAS janitors belonged to the category of extreme risk. Based on the results of interviews and identification, the danger and risk of wounds that can be experienced by janitors include needle puncture $(89.5 \%)$, scratches $(57.9 \%)$, inhaled cleaning chemicals $(42.3 \%)$, in direct contact with public toilets and patient rooms (93.7\%), and blood or urine spills $(73.7 \%)$, non-ergonomic work postures from frequent bending, lifting, and transferring collected hospital waste (100\%). As a result, janitors often complained of health problems such as sore eyes, musculoskeletal complaints, low back pain, dizziness, nausea, vomiting, and infection with fever. The risks faced by janitors were generally exposure to germs, bacteria, and viruses and high risk chemotherapy drugs $(36.6 \%)$; the risk of needle sticking or sharp scratches, slipping, musculoskeletal disorders, falling from a ladder, and electrocution as moderate risk (45.1\%); and the risk of allergies or irritation to the use of chemicals as low risk (18.3\%) [29].

Based on other research, the risk of medical waste was from the potential pathological organisms [30]. If improperly managed, it may be a risk to health workers and the public [31]. On the other hand, medical solid waste was placed together with the non-clinical waste which created unavoidable health risks [32]. Therefore, the waste generated from hospitals and clinics had become a focal point due to its consequences as a threat to the health of patients, health-care staff, and outside the medical establishment [33]. Moreover, healthcare workers were not aware of the risks associated with medical waste [34]. Studies showed that the health personnel dealing with medical waste were affected by the biological, physical, and chemical hazards such as needle sticks, cuts, falls, strains, sprains, burns, eye, and back injuries. Several injuries such as cuts due to handling broken glass occurred due to exposure to medical waste inside and outside hospital premises [35]. The World Health Organization (WHO) also confirmed the risks associated with infectious waste and sharps that nurses are exposed to during healthcare delivery [30].

Cleaners are also very potential to experience musculoskeletal complaints because the average work pattern is still done manually such as sweeping, mopping, cleaning the toilet, transporting garbage which directly uses body postures such as bending, squatting and standing, repetitive movements, and high working frequency. This is in accordance with [36] the study where the erroneous and risk of ergonomic hazard postures are due to manual work when moving medical waste from the trash to medical waste plastic bags, wrong postures, and repetitive work when sweeping, mopping, and lifting medical waste.

The waste sorted by the cleaning team was then stored in a warehouse that served as a Temporary Storage Place (TSP) from H-USU (See Figure 2). The waste that had been collected was not managed by the hospital except for liquid waste. Actually, the hospital has an incinerator, but it cannot be used to manage waste. Therefore, infectious waste placed at the polling station is sub-contracted back to SDLI (Sumatera Deli Lestari Indah), Ltd. for management. It should be noted that this polling station must always be neatly closed and tightly locked to avoid biological or chemical exposure from the collected garbage interacting with the hospital environment through air. This risk can lead to environmental pollution which can directly or indirectly affect safety and health in the hospital work environment. Owing to the toxic nature of medical waste, if there is improper handling, it may lead to the destruction of the natural environment. This may eventually cause a disruption in the balance of the prevailing ecosystem. Even though both the private clinic and hospital have established medical waste practices aiming at minimizing health risks, there were still environmental consequences [37].

\section{Conclusions}

Based on the study results, it can be concluded that the behavior of health providers in managing hospital waste was still poor. Some of the poor behaviors including not disposing of the garbage in accordance to the container that has been provided and determined by the hospital management, disposing sharp, infectious waste mixed with other garbage, and not caring about disposing the garbage into its place while disregarding the suitable waste containers. This behavior resulted in 
a very high risk of accident for janitors who manage waste in hospitals and are included in the extreme risk category.

To solve this problem, we need to create an innovation related to increasing the occupational safety and health standard procedure for janitors. The hospital has prepared special red garbage bags with markers of needle stick injuries to help janitors classify the infectious waste. A good discipline following SOP will help in the program implementation.

\section{Acknowledgments}

Thank you to the Director of Hospital USU who gave support for this study and all health providers as study participants. We also thank the staff of $\mathrm{H}-\mathrm{OSH}$ Unit who work together on solving the waste management problem. Thank you to the HIDC Unit for the advice and participation in waste management disposal. Thank you to the hospital management staff for making the hospital documentation available for study purposes. We also thank Sisca's team for data collection. We gratefully acknowledge the partial financial support from Lembaga Penelitian USU with the TALENTA Program of PPRSUSU with contract number: 2590/UN5.1.R/ PPM/KP-TALENTA USU/2018 date: 16 March 2018.

\section{References}

1. Undang-Undang Republik Indonesia. Undang-Undang Republik Indonesia Nomor 44 Tahun 2009 Tentang Rumah Sakit. Jakarta: Republik Indonesia; 2009. https://doi.org/10.31219/osf.io/xtdba

2. Seida YA, Moemen MM, Moustafa MS, Raouf ME, Elshaer NS. Hepatitis-C virus infection and exposure to blood and body fluids among nurses and paramedical personnel at the alexandria university hospitals, Egypt. Alex J Med. 2018;54(3):265-71. https://doi.org/10.1016/j.ajme.2017.06.005

3. Belachew YB, Lema TB, Germossa GN, Adinew YM. Blood/ body fluid exposure and needle stick/sharp injury among nurses working in public hospitals; Southwest Ethiopia. Front Public Health. 2017;5:1-6.

4. Markovic-Denic L, Maksimovic N, Marusic V, Vucicevic J, Ostric I, Djuric D. Occupational exposure to blood and body fluids among health-care workers in Serbia. Med Princ Pract. 2015;24(1):36-41. https://doi.org/10.1159/000368234 PMid:25376432

5. Chalya PL, Seni J, Mushi MF, Mirambo MM, Jaka H, Rambau PF, et al. Needle-stick injuries and splash exposures among healthcare workers at a tertiary care hospital in North-Western Tanzania. Tanzan J Health Res. 2015;17(2):1-15. https://doi. org/10.1186/s13104-015-1348-9

6. Al-Khatib IA, El Ansari W, Areqat TA, Darkhawaja RA, Mansour SH, Tucktuck MA, et al. Occupational safety precautions among nurses at four hospitals, Nablus district, Palestine. Int J Occup Environ Med. 2015;6(4):243-6. https:// doi.org/10.15171/ijoem.2015.581

PMid:26498052

7. Undang-Undang Republik Indonesia. Undang-Undang Republik Indonesia Nomor 18 Tahun 2008 Tentang Pengelolaan Sampah. Jakarta: Republik Indonesia; 2008. https://doi.org/10.31219/osf. io/pmwny

8. Keputusan Menteri Kesehatan Republik Indonesia. Keputusan Menteri Kesehatan Republik Indonesia No 1204 Tahun 2004 Tentang Persyaratan Kesehatan Lingkungan Rumah Sakit. Jakarta: Kementerian Kesehatan Republik Indonesia; 2004. https://doi.org/10.29238/sanitasi.v8i2.6

9. Adisasmito W. Health System. Edisi Kedua Jakarta: Rajawal Pers; 2014.

10. Garus-Pakowska A, Szatko F, Ulrichs M. Work-related accidents and sharp injuries in paramedics-illustrated with an example of a multi-specialist hospital, located in central Poland. Int J Environ Res Public Health. 2017; 14(8):1-13. https://doi.org/10.3390/ ijerph14080901

PMid:28796193

11. Dahlan SM. Besar Sampel dan Cara Pengambilan Sampe Dalam Penelitian Kedokteran dan Kesehatan. Jakarta: Salemba Medika; 2013.

12. Praktinya A. Dasar-dasar Metodologi Penelitian Kedokteran dan Kesehatan. Jakarta: Raja Grafindo Persada; 2011.

13. Asante BO, Yanful E, Yaokumah BE. Healthcare Waste Management; its impact: A case study of the greater Accra region, Ghana. Int J Sci Technol Res. 2014;3(3):106-12. https:// doi.org/10.2139/ssrn.2410909

14. Akpieyi A, Tudor TL, Dutra C. The utilisation of risk-based frameworks for managing healthcare waste: A case study of the national health service in London. Saf Sci. 2015;72:127-32. https://doi.org/10.1016/j.ssci.2014.08.014

15. Yilmaz A, Serinken M, Dal O, Yaylacl S, Karcioglu O. Workrelated injuries among emergency medical technicians in Western Turkey. Prehosp Disaster Med. 2016;31(5):505-8. https://doi.org/10.1017/s1049023×16000741 PMid:27491511

16. Clarke SP. Hospital work environments, nurse characteristics, and sharps injuries. Am J Infect Control. 2007; 35(5):302-9. https://doi.org/10.1016/j.ajic.2006.07.014 PMid: 17577476

17. Suzuki K, Ohida T, Kaneita Y, Yokoyama E, Miyake T, Harano S, et al. Mental health status, shift work, and occupational accidents among hospital nurses in Japan. J Occup Health. 2004;46(6):448-54. https://doi.org/10.1539/joh.46.448 PMid: 15613767

18. Carducci A, Federigi I, Verani M. Virus occupationa exposure in solid waste processing facilities. Ann Occup Hyg. 2013;57(9):1115-27. https://doi.org/10.1093/annhyg/met043

19. Kralj D, Stamenković M. Health Care Waste Management. WSEAS Trans Environ Dev. 2008;4(4):379-88.

20. Afolabi OT, Aluko OO, Afolabi BK, Fehintola FO. Healthcare waste management practices and risk perception of healthcare workers in private healthcare facilities in an urban community in Nigeria. Afr J Environ Sci Technol. 2018;12(9):305-11. https:// doi.org/10.5897/ajest2018.2534

21. Sudiharti S. Relationship between knowledge and attitude towards nurse behavior in disposal of medical waste at PKU Muhammadiyah hospital Yogyakarta. J Public Health. 2013;6(1):49-59. https://doi.org/10.12928/kesmas.v6i1.1017

22. Tudor TL, Barr SW, Gilg AW. Linking intended behaviour and actions: A case study of healthcare waste management in the Cornwall NHS. Resour Conserv Recycl. 2007;51:1-23. https:// doi.org/10.1016/j.resconrec.2006.06.009

23. Boyce JM. Environmental contamination makes an important 
contribution to hospital infection. J Hosp Infect. 2007;65(Suppl 2):50-4. https://doi.org/10.1016/j.resconrec.2006.06.009

24. Ferreira V, Teixeira MR. Healthcare waste management practices and risk perceptions: Findings from hospitals in the Algarve region, Portugal. Waste Manag. 2010;30(12):2657-63. https://doi.org/10.1016/j.wasman.2010.07.012

PMid:20713307

25. Pullishery F, Panchmal GS, Siddique S, Abraham A. Awareness, knowledge and practices on bio-medical waste management among health care professionals in mangalore a cross sectional study. Int Arch Integr Med. 2016;3(1):29-35.

26. Muluken A, Haimanot G, Mesafint M. Healthcare waste management practices among healthcare workers in healthcare facilities of Gondar town, Northwest Ethiopia. Health Sci J. 2013;7(3):315-26.

27. Maironah M, Subari D, Mariani M, Noor E. Behavior of Medical Worker in Managing Medical Waste in Ulin General State Hospital Banjarmasin. EnviroScienteae. 2011;7(2):93-102.

28. McKee M, Healy J. The role of the hospital in a changing environment. Bull World Health Organ. 2000;78(6):803-10. PMid:10916917

29. Yuantari MC, Nadia H. Safety and health Risk Analysis in Janitors at Faletehan Hospital. J Heal. 2018;5(3):107-16. https://doi.org/10.33746/fhj.v5i3.20

30. Alagöz AZ, Kocasoy G. Determination of the best appropriate management methods for the health-care wastes in İstanbul. Waste Manag. 2008;28(7):1227-35. https://doi.org/10.1016/j. wasman.2007.05.018

PMid:17707634
31. Shinee E, Gombojav E, Nishimura A, Hamajima N, Ito K. Healthcare waste management in the capital city of Mongolia. Waste Manag. 2008;28(2):435-41. https://doi.org/10.1016/j. wasman.2006.12.022

PMid: 17467969

32. Bendjoudi Z, Taleb F, Abdelmalek F, Addou A. Healthcare waste management in Algeria and Mostaganem department. Waste Manag. 2009;29(4):1383-7. https://doi.org/10.1016/j. wasman.2008.10.008

PMid: 19091540

33. Rastogi V, Rastogi P, Bhatia S. Bacteriological profile of biomedical waste: Management guidelines. J Indian Acad Forensic Med. 2011;33(2):145-8.

34. Katoch S. Biomedical waste classification and prevailing management strategies. In: Proceedings of the International Conference on Sustainable Solid Waste Management. Proceedings of the International Conference on Sustainable Solid Waste Management; 2007. p. 169-75. https://doi. org/10.1002/9781119035848.ch6

35. Nasima A. Medical Waste Management: A Review. School of Environment, Resources and Development. Thailand: Asian Institute of Technology; 2000.

36. Prasetio DB, Hasanbasri M, Hastaryo J. Ergonomical Risk Hazard in Outsourced Janitors at Sleman General Hospital. J Kesehat Masy Indones. 2015;10(1):10-6.

37. Bokhoree C, Beeharry Y, Makoondlall-Chadee T, Doobah T, Soomary N. Assessment of environmental and health risks associated with the management of medical Waste in Mauritius. APCBEE Procedia. 2014;9:36-41. https://doi.org/10.1016/j. apcbee.2014.01.007 